\title{
The archaeology of contact in southern patagonia: some issues to be resolved in the southwestern forest
}

\begin{abstract}
The use of new raw materials, particularly glass, stoneware and metal, for manufacturing traditional indigenous weapons has been so far one of the main lines of evidence of the archaeology of contact in mainland southern Patagonia (southernmost South America). Here, a new finding for the southwestern forest in Argentina is presented. This information is useful to discuss chronology, different strategies of European material procurement (direct or indirect) among local indigenous populations, and the role of the southwestern forest in native land use patterns during the contact period.
\end{abstract}

Keywords: archaeology of contact, European raw materials, southern Patagonia, forest land use patterns
Volume I Issue 4 - 2017

\author{
María Cecilia Pallo,' Karen Borrazzo² \\ 'Multidisciplinary Institute of History and Human Sciences- \\ National Council of Scientific and Technical Research, Argentina \\ ${ }^{2}$ Multidisciplinary Institute of History and Human Sciences- \\ National Council of Scientific and Technical Research, University \\ of Buenos Aires, Argentina
}

Correspondence: María Cecilia Pallo, Multidisciplinary Institute of History and Human Sciences-National Council of Scientific and Technical Research, Argentina, Email ceciliapallo@gmail.com

Received: October 24, 2017 | Published: December 21, 2017

\section{Introduction}

The use of glass as lithic raw material for traditional technological forms is recorded in several aboriginal archaeological contexts from South America, ${ }^{1-5}$ United States, ${ }^{6-8}$ India, ${ }^{9}$ Africa ${ }^{10}$ and Oceania, ${ }^{11-14}$ among others. These flaked artifacts are commonly associated with contact encounters during European colonial expansion ${ }^{7,11,14-18}$ and they are described as remanufactured glass. ${ }^{19}$ According to Martindale \& Jukavik, ${ }^{2,19}$ two of the issues addressable in the analysis of indigenous remanufactured glass artifacts are:

i. The identification of them via analyses derived from lithic studies

ii. The interpretation of their historical significance. Here we briefly address these topics for the case study of Southern Patagonian forest.

The archaeology of contact in mainland southern Patagonia, the southernmost region of both Argentina and Chile, still has a lot to say about the significant changes in the history and life ways of indigenous populations caused by the European colonization of the Americas. The incorporation of new raw materials, particularly glass, stoneware and metal, into the manufacture of traditional indigenous weapons has been so far one of the main ways of exploring these changes. ${ }^{20-32}$

These exotic materials were obtained by local indigenous groups, highly mobile hunter-gatherers (although they were less and less mobile with the advance of the European colonization), ${ }^{33}$ through a wide variety of contact situations with Europeans, ${ }^{34,35}$ after the Spanish arrival at the southern Atlantic coast of Patagonia in $1520 .{ }^{36}$ The current spatial distribution of archaeological remains on mainland southern Patagonia indicates that most of the artifacts manufactured on these new raw materials, especially glass, are recorded in archaeological sites located on the eastern steppes, and to a lesser extent within the western mountain forests or the transition zone between forest and steppe (Figure 1). This paper presents new data from an archaeological site located in southwestern Patagonian forest, which allow addressing questions about the contact period within this environment that remain unanswered.

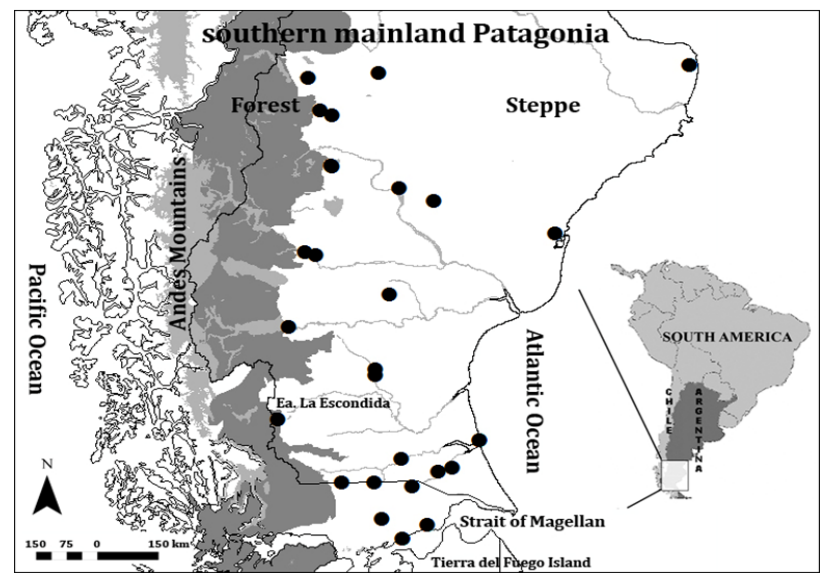

Figure I Southern mainland Patagonia: distribution of European materials recorded from archaeological sites of hunter-gatherers.

\section{The Southwestern forest in mainland southern patagonia}

Explorers who travelled along mainland Patagonia during the XIX century and the early XX century mentioned the limited use of the southwestern forest by historical indigenous groups, ethnographically known as "Aónikenk" or "Tehuelches meridionales". ${ }^{37}$ Their chronicles note the mobility and settlement patterns of local groups led by the "caciques" Mulato ${ }^{38} \&$ Blanco, ${ }^{39}$ and the exploitation of forest fruits when resources were scarce among the natives. ${ }^{40}$ The boundary between forest and steppe also appears to have been a key pathway for mobility on horseback between the southern coast and the inland. ${ }^{29,40-43}$

Despite the historical sources, a first archaeological survey of the area recorded scattered findings in the transition zone between forest 
and steppe, but no artifact were registered in the forest. ${ }^{44}$ Subsequent studies resumed surveying in the "empty zone", redefining an archaeological scenario of sporadic but repeated occupations by hunter-gatherers..$^{20,37,45-47}$ Among the latter a new surface open air site, named Ea. La Escondida was added (Figure 1). The site is located high on a hill (ca. 300mts), on the east margin of the Guillermo river valley. This stretch of the Guillermo River is set within the current transition zone between forest and steppe, although it should have been part of the forest until recently. ${ }^{48}$

Ea. La Escondida site records a lithic assemblage, represented by 54 small flakes on locally available shale, and one flake on clear glass (Figure 2). It is worth mentioning that no other glass artifacts or European materials were recorded at the site nor in the neighbor area. The glass flake $(1.9 \times 2.3 \times 2 \mathrm{~mm})$ is too small to allow a reliable identification of the object from which it was obtained. However, several technological and taphonomic traits on this single finding allow further discussion. The flake is thin, flat and wide and exhibits a small parallel flaking scar on the dorsal face, indicating the use of a single percussion (pressure) platform. Platform angle is $>120^{\circ}$ which jointly with the thin, flat and wide shape of the flake and the diffused bulb of percussion agree with (bifacial?) thinning process, probably by pressure. Similar technological attributes were exhibited by the shale flakes, which in turn emphasize the common technological background of local hunter gatherers. As for the study of taphonomic traits on the glass flake, it allowed to detect a remnant surface (platform and adjacent edge on dorsal face) that shows differential weathering (mainly abrasion) suggesting differential subaerial exposition times. That is to say that the flake from Ea. La Escondida was detached from a piece of glass which had been previously exposed to weathering/erosion processes for some time (deposited in a rubbish dump of a European ranch?). Taking technological and taphonomic data together, Ea. La Escondida finding suggests that an indirect provisioning strategy for glass (i.e. gathering from a rubbish dump, collected on the coast, see below) cannot be ruled out.

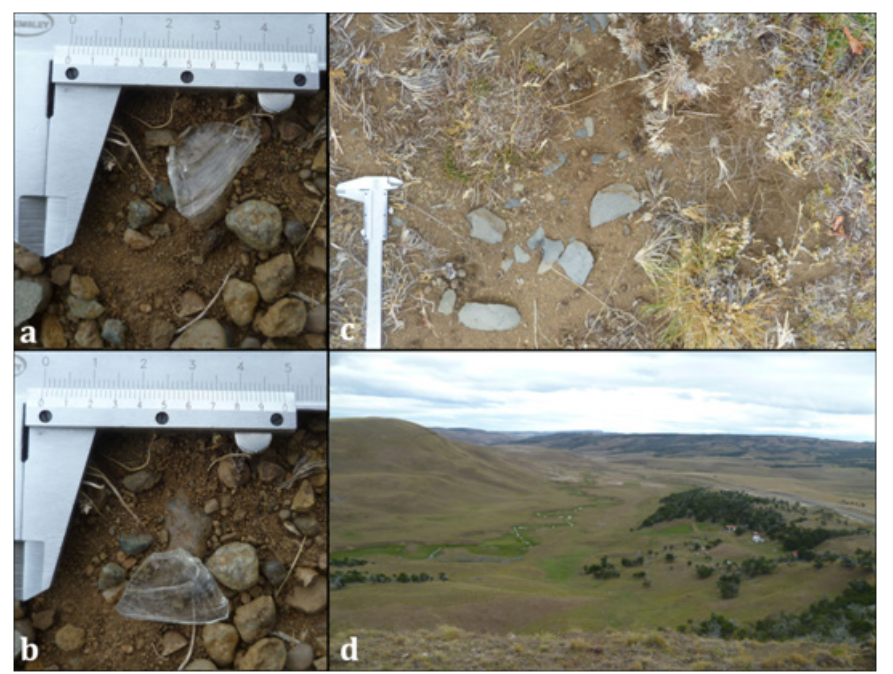

Figure 2 Ea. La Escondida site: (a) Dorsal and (b) ventral faces of the glass flake; (c) lithic assemblage on locally available shale; (d) location and view to the Guillermo river valley.

A likely chronology for the archaeological context could be the incorporation of these spaces into the political economy of Capitalism, occurred with the advance of the sheep farming frontier between 1900 and 1922 AD. ${ }^{49}$ However, to find out how European raw material was obtained by local hunter-gatherers is also required.
Either, direct interactions with Europeans or situations that did not require direct confrontation could be involved in the acquisition of these materials by the natives. ${ }^{34,35}$ Indirect contacts refer mainly to the numerous shipwrecks occurred in the Patagonian coasts during the XVII century. ${ }^{50}$ The impact of shipwrecks in the availability of raw material in southern Patagonia could implicate an early chronology for the procurement of European materials among the natives, even prior to the beginning of the European settlement of the region (since the end of the XIX century $\left.{ }^{49}\right) .^{35,51-52}$

A final issue to be solved is the role of this forest area in the land use patterns of hunter-gatherers during the contact period. In particular, if this sector was used by displaced indigenous groups and/or natives seeking to avoid contact with colonizers who were inhabiting European settlements in favored lands ${ }^{53-57}$ or it became a place adequate for interactions, given that, once European materials were incorporated into the life ways of indigenous groups, the increasing availability of European settlements would have made the procurement of this materials easier and predictable. ${ }^{22,35}$ Until now, the co-occurrence towards the end of the XIX century and the early XX century of a high use of glass in the manufacture of indigenous weapons and the early creation of farming sites and small villages supports this idea for mainland southern Patagonia. ${ }^{58}$ Nevertheless, the taphonomic trends recorded on the finding of Ea. La Escondida suggests that an indirect provisioning strategy (involving scavenging and reclamation processes) is an feasible alternative for glass procurement in southwestern forest environment of mainland Patagonia.

\section{Conclusion}

The archaeology of contact shows heterogeneous and contrasting spatial contexts for traditional indigenous weapons manufactured with European raw materials among different areas of southern Patagonia. These differences area explained as a result of a number of key factors interacting with one another to varying extents in the mainland. ${ }^{32}$ This is, the introduction of the horse as a resource exploited in many ways by native people since the XVIII century, ${ }^{59,60}$ the integration of commercial networks based on local resources such as guanaco (Lama guanicoe, the main prey of indigenous groups) into a newly imposed political economy of Capitalism, changes in original home range sizes, settlement and demographic patterns of mobile hunter-gatherers, ${ }^{53-57,61-63}$ as well as the establishment of European settlements, sheep farms and indigenous reserves since the XIX century. ${ }^{49}$

New archaeological data presented here begin to glimpse advances in the information available for the southern western forest in mainland southern Patagonia. These findings are still few, but they already point out that the previously boundary established for the spatial distribution of historical indigenous populations ${ }^{44}$ needs to be revised. ${ }^{45}$ This information also posits specific key aspects that need to be addressed by the archeology of contact: how much further into the western forest will traditional indigenous artifacts manufactured on European raw materials could be recorded?, what forms of European raw material procurement (direct or indirect) among local indigenous populations were involved?, and what role did the southwestern forest play into the land use patterns of historical hunter-gatherers settled in mainland southern Patagonia? Finally, data presented here is a new contribution to approaches on hunter-gatherer populations within the context of historical culture-contact dynamics, since the use of European raw materials to manufacture traditional weapons is often identified on a wide variety of archaeological sites around the world. ${ }^{1-35}$ 


\section{Acknowledgements}

We thank the editor and anonymous reviewers for their constructive comments, which helped us to improve the manuscript. We also thank Luis A Borrero for their support and help. This research was supported by CONICET and ANPCyT (PICT2014-2061).

\section{Conflict of interest}

The author declares no conflict of interest.

\section{References}

1. Casamiquela R. Temas patagónicos de interés arqueológico III. La técnica de la talla de vidrio. Relaciones XII. 1978:213-222.

2. Conte IC, Romero FG. Microwear Analysis of Retouched Glass Fragments from Fortlet Miñana, Azul, Argentina, 1860-1863. International Journal of Historical Archaeology. 2008;12(3):248-262.

3. Lothrop SK. The Indians of Tierra del Fuego. USA: Contrib Museum of the American Indian; 1928. $10 \mathrm{p}$.

4. Macedo JHS. Garrafas, frascos e pontas de flecha. Considerações sobre o vidro do sítio da Guarda de São Martinho. RS Cepa. 1997;21(26):91-112.

5. Souza MAT. A vida escrava portas adentro:uma incursão nas senzalas do Engenho de São Joaquim, Goiás, Século XIX. Maracanan. 2011;7(7):83-109.

6. Clark JT. Glass scrapers from historic North America. Newsletter of Lithic Technology. 1981;10(2):31-34.

7. Porter C. Identification and Analysis of Utilized Glass in Early Colonial Contexts: A Case Study from $17^{\text {th }}$-Century Rhode Island. Technical Briefs in Historical Archaeology. 2015;9:1-15.

8. Wilkie LA. Glass-knapping at a Louisiana Plantation: African-American Tools? Historical Archaeology. 1996;30(4):37-49.

9. Cooper Z, Bowdler S. Flaked glass tools from the Andaman Islands and Australia. Asian Perspectives. 1998;37(1):76-83.

10. Chazan M, Porat N, Alexandra Sumner T, et al. The use of OSL dating in unstructured sands: The archaeology and chronology of the Hutton Sands at Canteen Kopje (Northern Cape Province, South Africa) Archaeological and Anthropological Sciences. 2013;5(4):351-363.

11. Allen FJ. 1969 Port Essington: The historical archaeology of a north Australian nineteenth century military outpost. Studies in Australasian Historical Archaeology. 2008;1:79-88.

12. Allen FJ, Jones R. Oyster Cove: Archaeological traces of the last Tasmanians and notes on the criteria for the authentication of flaked glass artifacts. Papers and Proceedings of the Royal Society of Tasmania. 1980;114:225-233.

13. Goward T. Aboriginal glass artifacts of the Sydney region. Thesis a Bachelor of Arts (Honours) in Archaeology. Australia: The University of Sydney; 2011.

14. Ulm S, Vernon K, Robertson G, et al. Historical Continuities in Aboriginal Land-Use at Bustard Bay, Queensland: Results of UseWear and Residue Analysis of Aboriginal Glass Artifacts. Australasian Historical Archaeology. 2009;27:111-119.

15. Martindale A, Jurakic I. Identifying expedient glass tools in a post-contact Tsimshian village. Journal of Archaeological Science. 2006;33(3):414 427 .

16. Pedrotta V, Bagaloni V. Looking at Interethnic Relations in the Southern Border through Glass Remains: The Nineteenth-Century Pampa Region, Argentina. International Journal of Historical Archaeology. 2005;9(3):177-193.
17. Poplin EC. Expedient technology in European North America: Implications from an alternative use of glass by historic period populations. Canada: Unpublished $\mathrm{PhD}$ Thesis, University of Calgary; 1986.

18. Wackett MJ. Knapped Glass: a practice of all cultures. The Post Hole: The studentrun archaeology journal. 2015;43:20-27.

19. Martindale A, Jurakic I. Glass Tools in Archaeology: Material and Technological Change. Oxford Handbooks Online, 2015. p. 1-57.

20. Belardi JB, Carballo Marina F, Nuevo Delaunay A, et al. Raspadores de vidrio y de gres cerámico en la reserva tehuelche (Aonikenk) de Camusu Aike: Aportes al conocimiento de las poblaciones indígenas de los siglos XIX y XX en el territorio de Santa Cruz. Relaciones XXXVIII. $2013 ; 1: 37-57$

21. Buscaglia S, Nuviala V. Pocos espejitos de colores. La materialidad de las relaciones interétnicas en Floridablanca. In: Morello F, Prieto A, et al. editors. Arqueología de Fuego Patagonia. Levantando piedras, desenterrando huesos...y develando arcanos. Punta Arenas: CEQUA; 2007. p. 813-24.

22. Cirigliano NA. Movilidad de grupos indígenas y aprovechamiento de materias primas entre el extremo sur del Macizo del Deseado y la cuenca del río Santa Cruz durante los últimos 2.000 años (Provincia de Santa Cruz, Argentina). Argentina: PhD dissertation, Universidad de Buenos Aires; 2016.

23. Cirigliano NA, Vommaro MN. Historical occupations at the Southern Part of the Deseado Massif: The case of La Gruta 3 (Santa Cruz, Argentina). In: $78^{\text {th }}$ Annual Meeting, Society for America Archaeology. Society for America Archaeology, Honolulu, Hawaii; 2013. 101 p.

24. Gómez Otero J. Un raspador en vidrio confeccionado por una tehuelche meridional. Mundo Ameghiniano. 1987;7:1-3.

25. Goñi R, Nuevo Delaunay A. La Arqueología como "fuente" de la Historia. In: Salemme M, Santiago F, editors. Arqueología de la Patagonia: una mirada desde el último confín. Argentina: Editorial Utopías; 2009. $1: 149-158$.

26. Jackson D. Los instrumentos de vidrio de Cuarto Chorrillo, costa de Bahía Santiago, Estrecho de Magallanes. Anales del Instituto de la Patagonia. 1991;20:69-74.

27. Jackson D. Raspadores de vidrio en Dinamarquero: reflejo de una encrucijada cultural. Anales del Instituto de la Patagonia. 1991;20:5768.

28. Jackson D. Raspadores de vidrio en un asentamiento Aonikenk en el valle del Zurdo, zona central de Magallanes. Anales del Instituto de la Patagonia. 1999;27:175-81.

29. Martinic M, Prieto A. Dinamarquero, encrucijada de rutas australes. Anales del Instituto de la Patagonia. 1985;16:53-81.

30. Martinic M, Prieto A, Cárdenas P. Hallazgo del asentamiento del Jefe Aonikenk Mulato en el valle del Zurdo, una prueba de sedentarización indígena en el periodo histórico final. Anales del Instituto de la Patagonia. 1995;23:87-94.

31. Nuevo Delaunay A. Tecnología vítrea en el siglo XX, Lago Strobel (Santa Cruz, Argentina), In: Morello F, Prieto A, et al. editors. Arqueología de Fuego Patagonia. Levantando piedras, desenterrando huesos...y develando arcanos. Chile: CEQUA; 2007. p. 853-59.

32. Nuevo Delaunay A, Belardi JB, Carballo Marina F, et al. Glass and stoneware knapped tools among hunter-gatherers in southern Patagonia and Tierra del Fuego. Antiquity. 2017;91(359):1330-1343.

33. Goñi R. Cambio climático y poblamiento humano durante el Holoceno tardío en Patagonia Meridional. Una perspectiva arqueológica. Argentina: PhD dissertation, Universidad de Buenos Aires; 2010. 
34. Borrero LA. El registro arqueológico del contacto: enfermedad y discontinuidad poblacional. Palimpsesto. 1998;5:202-207.

35. Manzi L. Las fuentes etnohistoricas en el analisis de la explotacion y manejo de materias primas en grupos de cazadores-recolectores pedestres de la Isla Grande de Tierra del Fuego. In: Gómez Otero J, editor. Arqueología: Sólo Patagonia. Tecnología. Puerto Madryn: CENPAT-CONICET; 1996. p. 379-88.

36. Pigafetta A. Primer viaje en torno del globo. Argentina: Espasa Calpe; 1946.

37. Borrero LA, Borrazzo K. La geografía cultural del sudoeste de Patagonia continental. In: Borrero LA, Borrazzo K, editors. Bosques, montañas y cazadores. Investigaciones Arqueológicas en Patagonia Meridional. Buenos Aires: Impresiones Dunken; 2011. p. 7-36.

38. Childs H. El Jimmy, Bandido de la Patagonia. Punta Arenas: Universidad de Magallanes; 1997.

39. Martinic M. Marinos de a caballo. Exploraciones terrestres de la Armada de Chile en la Patagonia austral y la Tierra del Fuego 1877-1897. Chile: Universidad de Magallanes y Universidad de Playa Ancha; 2002.

40. Arms W, Coan T. Extracto de los diarios de los Señores... Revista de la Biblioteca Nacional. 1939;3(9):104-152.

41. Fitz Roy R. Narrative of the surveying voyages of His Majesty's Ships Adventure and Beagle between the years 1826 and 1836, describing their examination of the southern shores of South America, and the Beagle's circumnavigation of the globe. Proceedings of the second expedition, 1831-36, under the command of Captain Robert Fitz-Roy RN Henry Colburn, England; 1933.

42. Schmid T. Misionando por la Patagonia austral 1858-1865. Argentina: Academia Nacional de la Historia; 1964.

43. Massone M. Panorama etnohistórico y arqueológico de la ocupación Tehuelche y Prototehuelche en la costa norte del estrecho de Magallanes. Anales del Instituto de la Patagonia. 1979;10:63-108.

44. Gómez Otero J. Discusión sobre el límite occidental del territorio de los Proto-Tehuelches y Tehuelches meridionales en el extremo Sud de Patagonia (cuenca del río Gallegos). Waxen. 1991;6(3):3-22.

45. Borrero LA, Charlin J, Barberena R, et al. Circulación humana modos de interacción al sur del río Santa Cruz. In: Borrero LA, Franco NV, editors. Arqueología del sur de América del Sur. Buenos Aires: CONICET; 2008. p. $155-174$.

46. Carballo Marina F, Belardi JB, Borrero LA. Nuevos datos para la discusión arqueológica de corredores en el bosque del suroeste de la provincia de Santa Cruz, Argentina: El caso del arroyo Los Loros. Magallania. 2013;44(2):209-217.

47. Charlin J, Borrero LA, Pallo MC. Ocupaciones humanas en el área noroccidental del río Gallegos. In: Borrero LA, Borrazzo K, editors. Bosques, montañas y cazadores: investigaciones arqueológicas en Patagonia meridional. Buenos Aires: Dunken; 2011. p. 179-210.

48. Pallo MC, Borrero LA. Arqueología de corredores boscosos en Patagonia meridional: el caso del río Guillermo (SO de la provincia de Santa Cruz, Argentina). Intersecciones en Antropología. 2015;16(2):313-326.
49. Barbería EM. Los dueños de la tierra en la Patagonia Austral: 18801920. Río Gallegos: UNPA; 1995. 457 p.

50. Gusinde M. Los indios de Tierra del Fuego. 1 Los Selk'nam. Argentina: CAEA/CONICET; 1982.

51. Horwitz V, Borrero LA, Casiraghi M. San Julio 2 (Tierra del Fuego) Estudios del registro arqueológico. Relaciones de la Sociedad Argentina de Antropología XIX. 1994. p. 391-415.

52. Prieto A, Van de Maele M. Varazones de ballenas y siniestros en la costa nororiental del estrecho de Magallanes. Anales del Instituto de la Patagonia. 1995;23:95-103.

53. Aguerre AM. Las Vidas de Pati en la Toldería Tehuelche del Río Pinturas y el después. Argentina: Universidad de Buenos Aires; 2000.

54. Buscaglia S. Poder y dinámica interétnica en la colonia española de Floridablanca. Una perspectiva histórica y arqueológica (Patagonia, Argentina, Siglo XVIII). Saarbrücken: Editorial Académica Española; 2012. $476 \mathrm{p}$.

55. Nuevo Delaunay A. Disarticulation of Aónikenk Hunter-Gatherer Lifeways during the Late Nineteenth and Early Twentieth Centuries: Two Case Studies from Argentinean Patagonia. Historical Archaeology. 2012;46(3):149-164.

56. Goñi R. Arqueología de momentos históricos fuera de los centros de conquista y colonización: un análisis de caso en el sur de la Patagonia. In: Belardi JB, Carballo Marina F, editors. Desde el país de los gigantes. Perspectivas arqueológicas en Patagonia. Río Gallegos: UNPA; 2000. 1:283-293

57. Goñi R. Reacomodamientos poblacionales de momentos de momentos históricos en el noroeste de Santa Cruz. Proyecciones arqueológicas. In: Zangrando AF, Barberena R, editors. Tendencias teóricometodológicas y casos de estudio en la arqueología de la Patagonia. Argentina: Museo de Historia Natural de San Rafael; 2013. p. 389-396.

58. Cirigliano N, Pallo MC. Projectile points distribution within the last 2,000 years: changes from pre- to post-contact times in southern Patagonia. 2017.

59. Martinic M. Los Aónikenk, historia y cultura. Chile: Universidad de Magallanes; 1995.

60. Martinic M, Quiroz DL. El uso ecuestre entre los Aónikenk. Anales del Instituto de la Patagonia. 1989;19:29-42.

61. Boschín MT, Nacuzzi LR. Ensayo metodológico para la reconstrucción etnohistórica. Su aplicación a la comprensión del modelo tehuelche meridional. Serie Monográfica. 1979;4:1-39.

62. Gómez Otero J, Moreno JE. Archaeological evidence for hunter-gatherers mobility and diet changes during eighteen and nineteen centuries in the central Patagonian Atlantic coast. The SAA Archaeological Record. 2015;15(3):12-15.

63. Moreno JE, Videla BA. Rastreando ausencias: la hipótesis del abandono del uso de los recursos marinos en el momento ecuestre en la Patagonia continental. Magallania. 2008;36(2):91-104. 